\title{
1. INTRODUCTION AND EXPLANATORY NOTES, DEEP SEA DRILLING PROJECT LEG 58
}

\author{
George deVries Klein, University of Illinois, Urbana-Champaign \\ Kazuo Kobayashi, University of Tokyo, Ocean Research Institute \\ and \\ Stan M. White, Scripps Institution of Oceanography, La Jolla, California
}

\section{INTRODUCTION}

\section{Background}

The western Pacific Ocean is a topographically and tectonally complex region dominated by subduction of the Pacific plate and the Indo-Australian plate. Subduction goes on at a rate of nearly $10 \mathrm{~cm}$ per year and clearly defines a zone of tectonic compression. Yet the overlying plate is characterized both by island arcs of dominantly andesitic volcanism and by a series of backarc, or marginal, basins beyond the island arc. The back-arc basins are now known to form by a process analogous to sea-floor spreading, with new crust being generated within the basin along analogs of mid-ocean ridges. The tectonics of the back-arc basins are clearly extensional, which seems anomalous in view of the dominant compressional tectonics along the trenches defining the subduction zone. Evidence of formation of these basins by a process analogous to sea-floor spreading in mid-ocean regions includes the striped magnetic-anomaly patterns that characterize these basins; tholeiitic, oceanic basalts from dredging; and results of drilling during Legs $6,21,30$, and 31 of the Deep Sea Drilling Project.

Not all back-arc basins form by a simple spreading process, however. The Bering Sea Basin (Cooper et al., 1976) and the western Philippine Sea north of Daito Ridge and west of Kyushu-Palau Ridge (Hilde et al., (1977) may represent fragments of older oceanic crust trapped behind younger island arcs and trenches. These basins are floored by oceanic crust and are characterized by a striped magnetic-anomaly pattern.

In the case of the back-arc basins formed by sea-floor spreading, the mode of spreading also has been a problem. Differences in interpretation of magnetic-anomaly patterns and their associated age identification led to the proposal that spreading processes may be either symmetrical (Tomoda, et al., 1975; Watts and Weissel, 1975; Kobayashi and Isezaki, 1976; Kobayashi and Nakada, 1977, 1978; Louden, 1976, 1977) or single-limb (Watts and Weissel, 1975; Watts et al., 1977). Drilling into oceanic crust in these basins should resolve this problem.

The emplacement of oceanic crust within the backarc basins also raises some problems. Prior work on materials recovered by dredge hauls and from DSDP Legs $6,21,30$, and 31 indicated that these basins are floored by typical mid-ocean-ridge, tholeiitic basalts.
This finding is perhaps surprising, given the association of the back-arc basins with calc-alkaline island-arc volcanism. Petrologic questions that arise from a review of the prior work include the extent of similarities or differences between back-arc-basin basalts and typical mid-ocean-ridge basalts. Are the magma sources for the basalts emplaced in these two different tectonic domains similar or different? Is the material mantle-derived, as some claim, or is the source a partially melted subducted slab? What is the chemical variability of these back-arcbasin basalts? What kind of convective circulation is implied for the upper mantle and lower crust beneath these back-arc basins?

\section{Leg 58 Objectives}

Several objectives based on some of these major problems were developed by the JOIDES Active Margin Panel for Leg 58 in the north Philippine Sea. Drilling concentrated in the Shikoku Basin and the Daito Ridge and Basin province of the northwestern part of the Philippine Sea (Figure 1). The Shikoku Basin sites were selected to solve several problems concerning back-arc basins formed by ocean-floor spreading. Prior magnetic-anomaly mapping indicated that the Shikoku Basin formed by symmetrical spreading (Tomoda et al, 1975; Kobayashi and Isezaki, 1976; Kobayashi and Nakada, 1978; Watts and Weissel, 1975), although a single-limb process was also suggested (Watts and Weissel, 1975). Because of the magnetic-anomaly pattern, it was expected that drilling would result in recovery of basement basalts to determine the age of oceanic crust, and to answer some of the petrogenetic questions. Also, it was expected that drilling might resolve some outstanding problems related to sediment evolution during the rifting of the basin, as well as some general problems related to paleocirculation in the basin.

Therefore, our principal objectives in the Shikoku Basin were (1) to determine the age of the oldest sediment, so as to calibrate magnetic-anomaly ages and to provide a test for various spreading models suggested for the basin; (2) to investigate the mineralogy, petrology, and chemistry of basalt samples recovered by drilling, and to compare there basalts with those of midocean ridges, so as to understand the nature and source of magmatic materials in these basins; (3) to determine the distribution of sediment types in time, and to relate that distribution to the tectonic history of the basin; and 


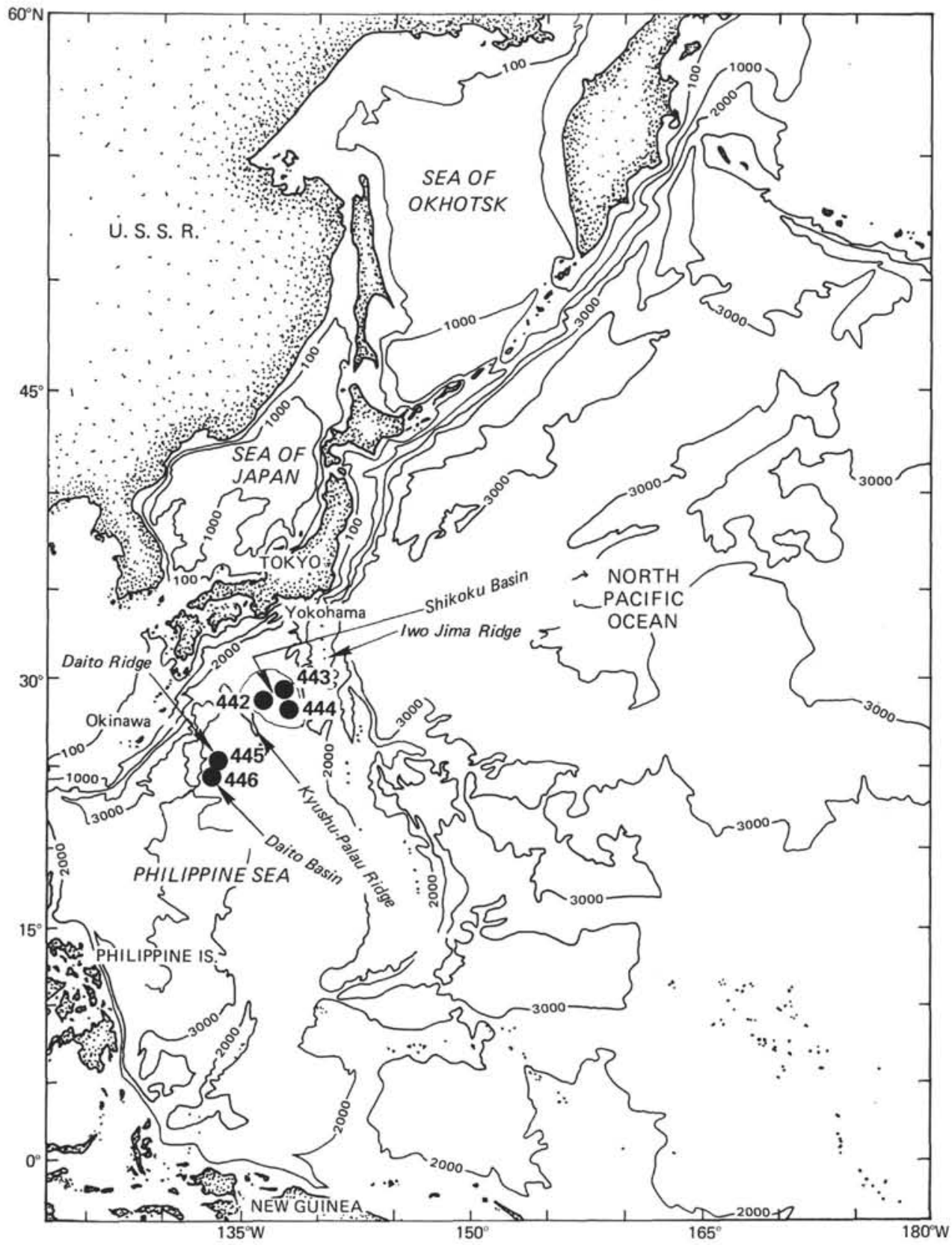

Figure 1. Location of DSDP Leg 58 sites. Bathymetry in meters.

(4) to determine the paleocirculation within the basin during its initial rifting history and during its postrifting history.

Sites in the Daito Ridge and Basin province were drilled with various objectives relevant to the origin of back-arc basins and related tectonic features. Prior work in the area, mostly dredging, had indicated great heterogeneity in the rocks from this region and the Amami Plateau to the north; metamorphic rocks (schists, gneisses), volcanic rocks (andesites, granodiorites, basalts), and sediments (mostly limestone) were recovered (Mizuno et al., 1975; Mizuno et al., in press; Shiki et al., 1974). Also, these dredged sedimentary rocks contain shallow-water foraminifers (Nummulites boni- nensis), indicating either regional subsidence (Konda et al., 1975; Mizuno et al., 1975) or considerable resedimentation. The amount of regional subsidence was therefore of interest.

The age of the oldest sediment and the underlying basement was also of interest. Prior work had indicated that the region to the north is an older back-arc basin floored by older Pacific crust entrapped by the development of the remanant arcs of Kyushu-Palau Ridge and Daito Ridge (Hilde et al., 1977), or formed by unidentified northward subduction of the Philippine Sea floor south of the Oki-Daito Ridge (Mizuno et al., 1975). Determinations of the age of the basement of the Daito Ridge and Basin province were expected to resolve the 
origin and age of the trapped basin. The Daito Ridge and Basin province was considered a remnant arc and inner-arc basin formed prior to the Kyushu-Palau Ridge, which was formed 47.5 Ma (Ozima et al., 1977).

Objectives of drilling in the Daito Ridge and Basin province were (1) to determine the age of acoustic basement, so as to establish the time of arc and back-arcbasin development; (2) to determine the mineralogy, petrology, and chemistry of acoustic-basement rocks and to compare them with mid-ocean basalts; (3) to determine the amount of subsidence of Daito Ridge since the Eocene; (4) to determine the relationships of sedimentation events to the tectonic evolution of this region; and (5) to investigate the paleoceanography of the region.

\section{Principal Results}

\section{Shikoku Basin (Sites 442, 443 and 444)}

Site 442 is in the west-central part of the Shikoku Basin, on magnetic anomaly 6 (19-21 m.y.). The stratigraphic section consists of 164 meters of Pleistocene mud and clay, 45 meters of Pliocene mud, 67 meters of late-Miocene mud and volcanic ash, 9.7 meters of earlyMiocene zeolitic clay and claystone, 0.4 meters of earlyMiocene limestone, 66 meters of massive basalt with normal magnetic polarity, and 92 meters of pillow basalt flows with normal polarity in the upper part and reverse polarity in the lower part. Continuous sedimentation started with pelagic limestone and clay which were succeeded by hemipelagic deposits formed at or near the calcite-compensation depth (CCD). The oldest sediment age, determined from a pelagic clay interbedded between the massive basalt and pillow lavas is early Miocene (18-21 m.y.), which is in agreement with the age of magnetic anomaly 6 . The basalt basement shows higherthan-normal vesicularity and is characterized by the absence of olivine. The basalts are of two kinds: extrusive pillow basalts produced by spreading processes, and intrusive basalt produced by later, off-ridge volcanism.

Site 443 is in the east-central part of the Shikoku Basin, on magnetic anomaly 6A (21-22 m.y.) The stratigraphic section consists of 44 meters of latePleistocene mud; 76 meters of early-Pleistocene nannofossil clay, clayey nannofossil ooze, and ash; 57 meters of late-Pliocene ash and clay; 29 meters of earlyPliocene mud; 57 meters late-Miocene mud and nannofossil ooze; 31 meters of late-Miocene mudstone; 45 meters of middle-Miocene nannofossil chalk and mudstone; 98 meters of claystone, mudstone, ash, and chalk of the early middle Miocene; a 35-meter interval of phyric olivine basalt with hydrothermal veins; 34 meters of pillow lava flows; and 47 meters of interbedded phyric basalts and pillow lava flows. Continuous sedimentation started with middle-Miocene resedimentation of volcaniclastic hemipelagic sediments, which were succeeded by post-middle-Miocene hemipelagic deposits formed slightly above the CCD. The age of the oldest recovered sediment is $15 \mathrm{~m}$.y., suggesting a basement age at variance with the age of magnetic anomaly $6 \mathrm{~A}$. The basalts show a combination of reversed polarity and normal polarity, with both high and low inclinations. Both pillow basalts, produced by crust generation at a spreading center, and intrusive basalt sills, produced by off-ridge volcanism, occur at this site. $\mathrm{A} \mathrm{K}-\mathrm{Ar}$ age determination of the youngest pillow shows its age to be $17.2 \pm 3.2$ m.y.B.P.

Site 444 is in the east-central part of the Shikoku basin, 45 nautical miles southeast of Site 443 , also on magnetic anomaly $6 \mathrm{~A}$. The stratigraphic section consists of 52 meters of Pleistocene interbedded mud, vitric mud, ash, and clayey nannofossil ooze; 32 meters of Pliocene mud, ash, and vitric mud; 110 meters of lateMiocene mud, ash, vitric mud, nannofossil ooze, radiolarian ooze, quartz sand, and siliceous mud; and 69 meters of middle-Miocene mudstone, ash, nannofossil ooze, and radiolarian mudstone, cut by a 10-meter basalt sill produced by off-ridge volcanism. This sill was dated as $14.2 \pm 2.1$ m.y. old ( $\mathrm{K}-\mathrm{Ar}$ method). Next below are 19 meters of amygdaloidal, phyric basalt, and another 19 meters of aphanitic, aphyric basalt. The sediments are dominated by a mixture of hemipelagic deposits and ash. The basalt section is entirely intrusive and a result of off-ridge volcanism. The age of the oldest sediment is $15 \mathrm{~m} . \mathrm{y}$., which is at variance with the magnetic-anomaly age at the site.

Sediments at the three sites are dominated by hemipelagic deposits formed slightly above the CCD. The lowest part of the sequence is dominantly smectite, whereas the younger parts show a progressive increase in kaolinite, illite, chlorite, vermiculite, palygorskite, and mixed-layer clays. This clay-mineral distribution reflects early supply of sediment from volcanic terranes, and later supply from a continental non-volcanic terrane. This increase in continent-derived clay, which starts in late Miocene, reflects a progressive cooling of the regional climate.

The basalts show chemical affinities with mid-oceanridge basalts, with minor evidence of fractional crystallization. A single magma source is inferred. The basalts were emplaced as pillow lavas, during the active spreading of the basin, and as off-ridge intrusive sills. The sills were identified by their massiveness; their grain coarseness; the predominance of fine-grained, chilled zones, rather than glassy zones; and the preservation of baked sediment at upper and lower contacts. The baked sediment was recognized by its composition and relative darkness, and by pyrolyzed organic matter in the sediment near the sill contact, found by shipboard analysis.

The oldest sediments at Site 442 are red pelagic clays found above pillow basalts, but below 59 meters of intrusives; they are dated paleontologically at 18 to 21 m.y., which agrees with the postulated age of magnetic anomaly 6 (Tomoda et al., 1975; Watts and Weissel, 1975; Kobayashi and Isezaki, 1976). The age of the sediment immediately above the intrusive is 15 to $17 \mathrm{~m}$.y., which is less than the postulated magnetic-anomaly age. At Sites 443 and 444, on magnetic anomaly 6A (21-22 m.y.), the oldest sediment occurs above basalt intrusives and is paleontologically dated at 14 to 15 m.y. A 10.5 -meter sill, whose age is $14.2 \pm 2.1 \mathrm{~m}$.y. intrudes younger sediments at Site 444 . The oldest dated 
sediments at Sites 443 and 444 are far younger than expected from a model assuming symmetrical sea-floor spreading (Tomoda et al., 1975; Kobayashi and Isezaki, 1976; Kobayashi and Nakada, 1978; Watts and Weissel, 1975). However, the sills underlying the oldest sediment at these two sites may well be considerably younger than true basement.

We have assumed that the pillow basalts at Sites 442 and 443 formed where sediment cover was relatively thin and unconsolidated or completely absent. Such an area could exist at or near an actively spreading ridge. Clearly, the massive basalt intrusives were emplaced after sedimentation occurred at all three sites. Thus, they post-date extrusion of the pillow basalts and, at any reasonable spreading rate, they must represent widespread off-ridge volcanism in the basin. This later volcanism occurred approximately from 13 to $15 \mathrm{Ma}$. This off-ridge volcanism has obscured contacts between sediments and original oceanic crust that may have formed originally at a spreading center or a ridge. The ages of the oldest sediments recovered at Sites 443 and 444 therefore may not be true basement ages. We conclude that ages of the oldest recovered sediments cannot be used to test models of the style of spreading in the Shikoku Basin.

\section{Daito Ridge and Basin Province (Sites 445, 446)}

Site 445 is in a small basin in Daito Ridge. The stratigraphic section consists of 141.5 meters of Pleistocene and Pliocene foraminifer-nannofossil ooze, 247 meters of early-Pliocene through early-Miocene foraminifer-nannofossil chalk, 275.5 meters of earlyMiocene through late-Eocene limestone with chert nodules in the lower part, 71 meters of middle-Eocene mudstone and sandstone with thin conglomerate beds, and 167 meters of middle-Eocene sandstone and conglomerate. Early-Oligocene sediments are absent. Nummulites boninensis is limited to beds of resedimented debris-flow conglomerate. Carbonate sediments, mudstones, sandstone, and conglomerate have been resedimented extensively by slumping, debris flows, and turbidity currents; nearly 60 per cent of the carbonate section has been resedimented. Paleomagnetic inclinations of samples indicate that Site $\mathbf{4 4 5}$ has migrated northward $2000 \mathrm{~km}$ from an equatorial latitude over the last $50 \mathrm{~m}$.y. Basement was not reached, because bad weather forced abondonment of the site. However, drilling terminated about 50 meters above acoustic basement, and if one assumes no hiatuses and high rates of sediment accumulation from the beginning of sedimentation, a basement age of approximately $50 \mathrm{~m}$.y. can be inferred by extrapolation.

Site 446 is in Daito Basin, south of Daito Ridge and north of Oki-Daito Ridge. The sedimentary section in this inner-arc basin consists of 14 meters of Pliocene terrigenous muds and clay; 158.5 meters of Pliocene, Miocene, Oligocene, and late-Eocene pelagic clay; 190 meters of middle to late Eocene mudstone, claystone, siltstone, and turbiditic sandstone of the middle Eocene to late early Eocene; and 266 meters of interlayered calcareous mudstone, siltstone, sandstone, conglomerate, and ash, intruded by 23 post-early-Eocene sills of titanium-rich basalt. A K-Ar age on one of the sills was determined to be $48.2 \pm 1.0 \mathrm{~m}$.y. Analysis of paleomagnetism shows that Site 446 has migrated northward about $2000 \mathrm{~km}$ from an equatorial latitude over the past $52 \mathrm{~m}$.y. Although basement was not reached, because of bit-wear, drilling terminated about 80 meters above acoustic basement. Assuming no hiatuses and that high sedimentation rates persisted from the beginning of development of Daito Basin, basement age may be 43 to 52 m.y. or more.

The sedimentary successions at these sites show remarkable similarities: a terrigenous, gravity-deposited, (basaltic) volcaniclastic succession, overlain by a pelagic succession. At Site 445 , the upper interval is a carbonate sequence, with both pelagic and resedimented carbonates; nearly 60 per cent of the carbonate sequence is resedimented by debris flow, slumping, and turbidity currents. At Site 446, the upper, pelagic succession consists of clay.

The large foraminifer Nummulities boninensis was encountered at several horizons of Site 445 , in debrisflow conglomerates and also as a significant component of sandstones deposited by turbidity currents. These were resedimented from a shoreline zone along an island arc, a finding corroborated by recovery of andesite clasts with the foraminifer fragments. This indicates that subsidence of Daito Ridge has been minimal: from sea level during Eocene time, to 1300 meters below sea level at present. The data require no other large-scale regional subsidence.

The 23 intrusive sills encountered at Site 446 are enriched in titanium and generally are more andesitic than tholeiitic. These sills were probably derived from the island arc now represented by the remnant arcs of Daito Ridge and Oki-Daito Ridge.

Paleomagnetism reveals that Sites 445 and 446 have drifted $2000 \mathrm{~km}$ northward from an equatorial latitude since about $50 \mathrm{Ma}$. The northward drift may have been associated with formation of the West Philippine Basin by symmetrical spreading. This spreading occurred after formation of the remnant-arc system of Daito and OkiDaito Ridges. In short, this remnant-arc region drifted north as new crust was generated in the West Philippine Basin, but its history is independent of the evolution of that basin

\section{Operations}

Basic data of the Leg 58 operation are summarized in Table 1.

\section{EXPLANATORY NOTES}

\section{Responsibilities for Authorship}

The authors of site-report chapters are the shipboard party collectively, ultimate responsibility lying with the two chief scientists. Chapters 2 through 6 present data and discussions on the holes drilled. All site-report chapters follow the same general outline (authors' names in parentheses). 
TABLE 1

Operations Summary for Leg 58

\begin{tabular}{lc}
\hline Total days (4 December 1977 to 30 January 1978) & 56.8 \\
Days in port & 7.04 \\
Days cruising, including site surveys & 9.0 \\
Days on site & 40.76 \\
Trip time & 8.84 \\
Drilling time & .86 \\
Coring time & 25.12 \\
Waiting on weather & 3.05 \\
Position ship & .54 \\
Mechanical repair & .25 \\
Re-entry & .55 \\
Other & 1.55 \\
Total distance traveled, including site surveys (nautical miles) & 1771 \\
Average speed (knots) & 7.25 \\
Sites & 5 \\
Holes drilled & 9 \\
Cores attempted & 324 \\
Cores with recovery & 322 \\
Cores with recovery (per cent) & 99.3 \\
Total coring (meters) & 2971.5 \\
Core recovery (meters) & 1591.82 \\
Core recovery (per cent) & 53.5 \\
Total drilling (meters) & 721.5 \\
Total penetration (meters) & 3759.5 \\
Part of total penetration cored (per cent) & 79.0 \\
Maximum penetration (meters) & 892.0 \\
Minimum penetration (meters) & 67.0 \\
Maximum water depth (meters) & 4952.0 \\
Minimum water depth (meters) & 3382.0 \\
\hline
\end{tabular}

Site Data

Background and Objectives (Klein and Kobayashi)

Operations (Klein and White)

Lithology (Curtis, Chamley, Mizuno, and White)

Organic Geochemistry (Waples)

Inorganic Geochemistry (White)

Biostratigraphy (Echols, Okada, Sloan)

Sedimentation Rates (Klein)

Igneous Petrography (Dick, Marsh, and Nisterenko)

Paleomagnetics (Kinoshita)

Physical Properties (Fountain)

Correlation (Kobayashi)

Summary and Interpretations (Klein and Kobayashi)

References

Appendix

The interpretations of individual authors have been retained in the section for which they were responsible. Therefore, conflict in between interpretations in a particular section and in the summary are sometimes apparent. Authors of special-topic chapters and the synthesis chapters are cited in the text.

\section{Survey and Drilling Data}

The survey data used for specific site selections are given in each site-report chapter. On passage between sites, continuous observations were made of depth, magnetic field, and sub-bottom structure. Short surveys were made on Glomar Challenger before dropping the beacon, using a precision echo sounder, seismic profiles, and magnetometer.

Depths were continuously recorded underway on a Gifft precision graphic recorder. The depths were read on the basis of an assumed 800 fathoms/s sounding velocity. The sea depth (in meters) at each site was cor- rected (1) according to the tables of Matthews (1939) and (2) for the depth of the hull transducer (6 meters) below sea level. In addition, any depths referred to the drilling platform have been calculated on the assumption that this level is 10 meters above the water line.

The seismic-profiling system consisted of two Bolt airguns, a Scripps-designed hydrophone array, Bolt amplifiers, two bandpass filters, and two EDO recorders, usually recording at two different filter settings.

\section{Drilling Characteristics}

Since water circulation down the hole is open, cuttings are lost onto the sea bed and cannot be examined. The only available information about sedimentary stratification between cores, other than from seismic data, is from an examination of the behavior of the drill string as observed on the drill platform. The harder the layer being drilled, the slower and more difficult it is to penetrate. However, there are a number of other variable factors which determine the rate of penetration, so it is not possible to relate this directly to the hardness of the layers. The parameters of bit weight and revolutions per minute are recorded on the drilling recorder and influence the rate of penetration.

\section{Drilling Disturbances}

When the cores were split, many showed signs of the sediment having been disturbed since its deposition. Such signs were the concave-downward appearance of originally plane bands, the haphazard mixing of lumps of different lithologies, and the near-fluid state of some sediments recovered from tens or hundreds of meters below the sea bed. It seems reasonable to suppose that these disturbances came about during or after the cutting of the core. Three different stages during which the core may suffer stresses sufficient to alter its physical characteristics are: cutting, retrieval (with accompanying changes in pressure and temperature), and core handling.

\section{Shipboard Scientific Procedures}

Numbering of Sites, Holes, Cores, and Samples

DSDP drill sites are numbered consecutively from the first site drilled by Glomar Challenger in 1968. Site numbers are slightly different from hole numbers. A site number refers to one or more holes drilled while the ship was positioned over one acoustic beacon. These holes could be within a radius as great as 900 meters from the beacon. Several holes may be drilled at a single site by pulling the drill pipe above the sea floor (out of one hole), moving the ship 100 meters or more from the previous hole, and then drilling another hole.

The first (or only) hole drilled at a site takes the site number. A letter suffix distinguishes each additional hole at the same site. For example: the first hole takes only the site number; the second takes the site number with suffix $A$; the third takes the site number with suffix $\mathrm{B}$, and so forth. It is important, for sampling purposes, to distinguish the holes drilled at a site, since recovered 
sediments or rocks from different holes usually do not come from equivalent positions in the stratigraphic column.

The cored interval is measured in meters below the sea floor. The depth interval of an individual core is the depth below sea floor that the coring operation began to the depth that the coring operation ended. Each coring interval is generally 9.5 meters long, which is the nominal length of a core barrel; however, the coring interval may be shorter or longer (rare). "Cored intervals" are not necessarily adjacent to each other, but may be separated by "drilled intervals". In soft sediment, the drill string can be "washed ahead" with the core barrel in place, but not recovering sediment, by pumping water down the pipe at high pressure to wash the sediment out of the way of the bit and up the space between the drill pipe and wall of the hole; however, if thin, hard rock layers are present, it is possible to get "spotty" sampling of these resistant layers within the washed interval, and thus have a cored interval greater than 9.5 meters.

Cores taken from a hole are numbered serially from the top of the hole downward. Core numbers and their associated cored interval in meters below the sea floor are normally unique for a hole; however, problems may arise if an interval is cored twice. When this occurs, the core number is assigned a suffix, such as " $\mathrm{S}$ "1 for supplementary.

Full recovery for a single core is normally 9.28 meters of sediment or rock, which is in a plastic liner $(6.6 \mathrm{~cm} \mathrm{I}$. D.), plus about a 0.2-meter-long sample (without a plastic liner) in the core-catcher. The core-catcher is a device at the bottom of the core barrel which prevents the core from sliding out when the barrel is being retrieved from the hole. The sediment core, which is in the plastic liner, is then cut into 1.5 -meter-long sections and numbered serially from the top of the sediment core (Figure 2). When full recovery is obtained, the sections are numbered from 1 through 7 , the last section possibly being shorter than 1.5 meters. The core-catcher sample is placed below the last section when the core is described, and labeled Core-Catcher (CC); it is treated as a separate section (for sediments only).

When recovery is less than 100 per cent, and if the sediment is placed in the top ${ }^{2}$ of the cored interval, then 1.5-meter-long sections are numbered serially, starting with Section 1 at the top. There will be as many sections as needed to accommodate the length of the core recovered (Figure 2); for example, 3 meters of core sample in plastic liners will be divided into two 1.5-meter-long sections. Sections are cut starting at the top of the recovered sediment, and the last section may be shorter than the normal 1.5-meter length.

\footnotetext{
${ }^{1}$ Note that this designation has been used on previous legs as a prefix to the core number for sidewall core samples.

2 This technique differs from the labeling systems used on Legs 1 through 45 , which had a designation called "zero section," but did not have a "number 7 section."
}

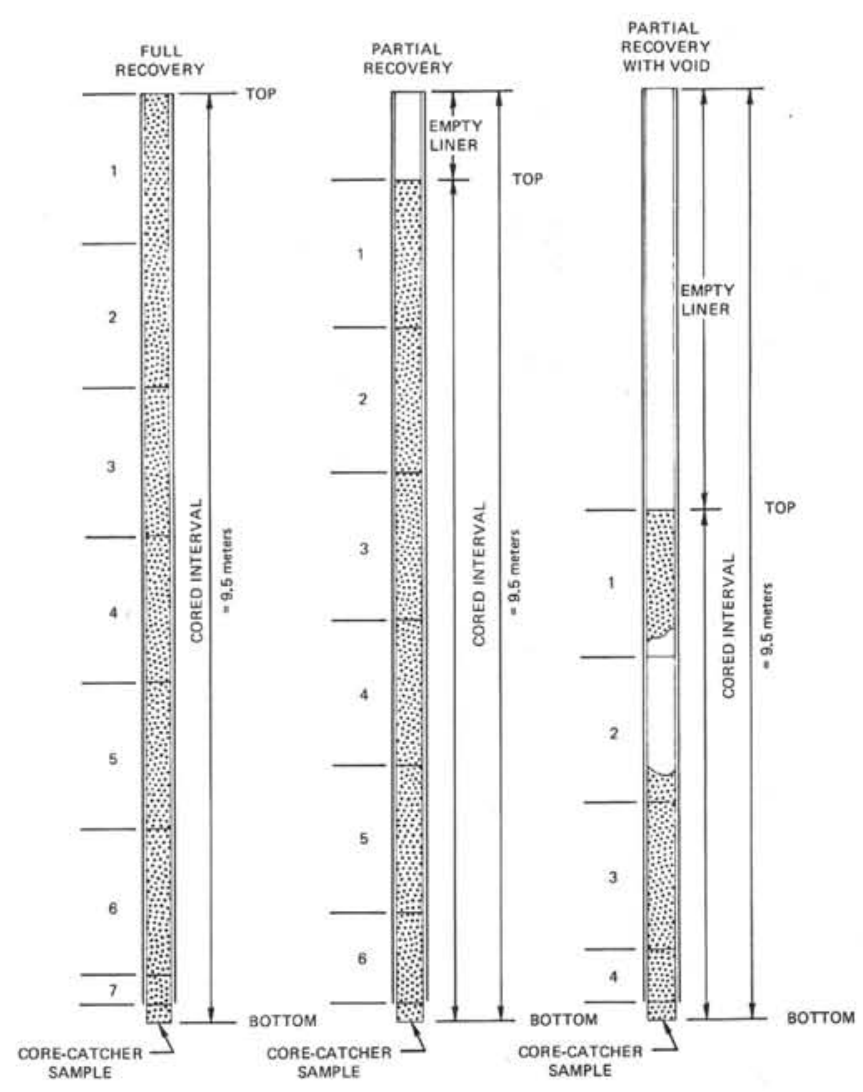

Figure 2. Diagram showing procedure in cutting and labeling of core sections.

When recovery is less than 100 per cent, the original stratigraphic position of the sediment in the cored interval is unknown; we conventionally attribute the top of the recovered sediment to the top of the cored interval. This is done for convenience in data handling, and for consistency. If recovery is less than 100 per cent, if the core is fragmented, and if shipboard scientists believe that the fragments were not originally contiguous, then sections are numbered serially and the intervening sections are noted as void, whether the fragments as found were contiguous or not.

Samples are designated by distances in centimeter from the top of each section to the top and bottom of the sample in that section. A full identification number for a sample consists of the following information: (1) Leg, (2) Site, (3) Hole, (4) Core Number, (5) Interval in centimeters from the top of the section.

For example, the sample-identification number " $58-442-9-3,12-14 \mathrm{~cm}$ " means that a sample was taken between 12 and $14 \mathrm{~cm}$ from the top of Section 3 of Core 9, from the first hole drilled at Site 442 during Leg 58. A sample from the core-catcher of this core is designated " $58-442-9$, CC, 12-14 cm".

The depth below the sea floor for a sample numbered " $58-442 \mathrm{~A}-9-3,12-14 \mathrm{~cm}$ " is the sum of (1) the depth to the top of the cored interval for Core 9 (76.0 meters); (2) plus 3 meters for Sections 1 and 2 (each 1.5 meters long); plus the $12 \mathrm{~cm}$ depth below the top of Section 3 . 
All of these variables add up to 79.12 meters, ${ }^{3}$ which theoretically is the sample depth below the sea floor.

\section{Handling of Cores}

A core was normally cut into 1.5 -meter sections, sealed, and labeled; the sections then were brought into the core laboratory for processing. The following determinations were normally made before the sections were split: gas analysis, thermal-conductivity analysis (soft sediment only), and continuous wet-bulk density determinations using the Gamma Ray Attenuation Porosity Evaluation (GRAPE).

The cores were then split longitudinally into "working" and "archive" halves. Samples extracted from the "working" half included tose for grain size analysis, determination of mineralogy by X-ray diffraction, measurement of sonic velocity by the Hamilton Frame method, measurement of wet-bulk density by a GRAPE technique, measurement of water content by gravimetric analysis, carbon-carbonate analysis, measurement of calcium-carbonate percentage (carbonate bomb), geochemical analysis, paleontological studies, and other studies.

The archive half was smoothed with a spatula on the cut surface to emphasize the sedimentary fatures. The color, texture, structure, and composition of the various lithologically different parts of a section were described on standard visual-ccre-description sheets (one per section), and any unusual features were noted. A smear slide was made, usually at $75 \mathrm{~cm}$ if the core was uniform. However, two or more smear slides were often made for each area of distinct lithology in the core section. The smear slides were examined by petrographic microscope. The archive half of the core section was then photographed.

After the cores were sampled and described, they were maintained in cold storage aboard Glomar Challenger until transferred to the DSDP repository. Core sections which were removed for organicgeochemistry study were frozen immediately aboard ship and kept frozen. All Leg 58 cores and frozen cores are presently stored at the DSDP West Coast Repository (Scripps Institution of Oceanography).

Material obtained from core catchers and not used up in the initial examination was retained in core liners for subsequent work. Sometimes significant pebbles from the core were extracted and stored separately in labeled containers. Sometimes the liners contained only sediment-laden water; this usually was collected in a bucket and allowed to settle, the residue being stored in freezer boxes.

Visual core descriptions, smear-slide descriptions, carbonate-bomb (per cent $\mathrm{CaCO}_{3}$ ) determinations (all done aboard ship), grain-size analyses, and carbon-carbonate determinations (both done at the DSDP shorebased laboratory) provide the data for the core descriptions in this volume. This information is summarized

\footnotetext{
${ }^{3}$ Sample requests should refer to a specific interval within a core section, rather than the depth below sea floor.
}

and sample locations in the core are indicated on the core-description sheets (Figure 3).

\section{Core Descriptions}

\section{Drilling Disturbance}

Recovered rocks, particularly soft sediments, may be extremely disturbed. This mechanical disturbance is a result of the coring technique, which uses a $25-\mathrm{cm}-$ diameter bit with a 6.0 -cm-diameter opening for the core sample. Symbols for the four disturbance categories used for soft and firm sediment are shown in Figure 4. These symbols are used on the core-description sheets. The disturbance categories are defined as follows:

Slightly disturbed: bedding contacts are slightly bent.

Moderately disturbed: bedding contacts have undergone extreme bowing.

Very disturbed: bedding is still more disturbed, sometimes showing symmetrical, diapir-like structures.

Soupy: sediment is water-saturated and original bedding is completely lost.

\section{Sedimentary Structures}

At the request of the ad hoc Committee on Symbolic Coding of Sedimentary Structures of the JOIDES Sedimentary Petrology and Physical Properties Panel, Leg 58 was designated to field test a set of newly proposed symbols for sedimentary structures. The symbols usd on Leg 58 core-description sheets are shown in Figure 5.

Color

Colors of the geologic material were determined with a Munsell or Geological Society of America Rock-Color Chart, immediately after the cores were split and while they were wet. Corresponding color codes are used on the core-description sheets.

\section{Lithology}

The core-description sheets include a graphic lithologic column. The symbols used in this column are explained in Figure 6. Figure 7 shows the textural classification used for clastic sediments. Often lithology will be represented in the column by a single pattern. Some lithologies are represented by a combination of two or more symbols. The symbols in this combination may correspond to end-member sediment constituents, such as clay and nannofossil ooze. The proportions of the components are represented in the graphic column by the relative widths of the symbols. For example, the left 20 per cent of the column may have a clay symbol, while the right 80 per cent of the column may have a nannofossil-ooze symbol. This means that the core interval is approximately 80 per cent nannofossil ooze and 20 per cent clay. Figure 3 shows actual examples, some with third and fourth lithologies indicated.

Because the width of the graphic lithologic column is exaggerated with respect to core length, it is not possible to represent structures as they appeared in the core. (They become flattened and distorted.) The same is true for erratic pebbles and changes of lithology in the cores. 


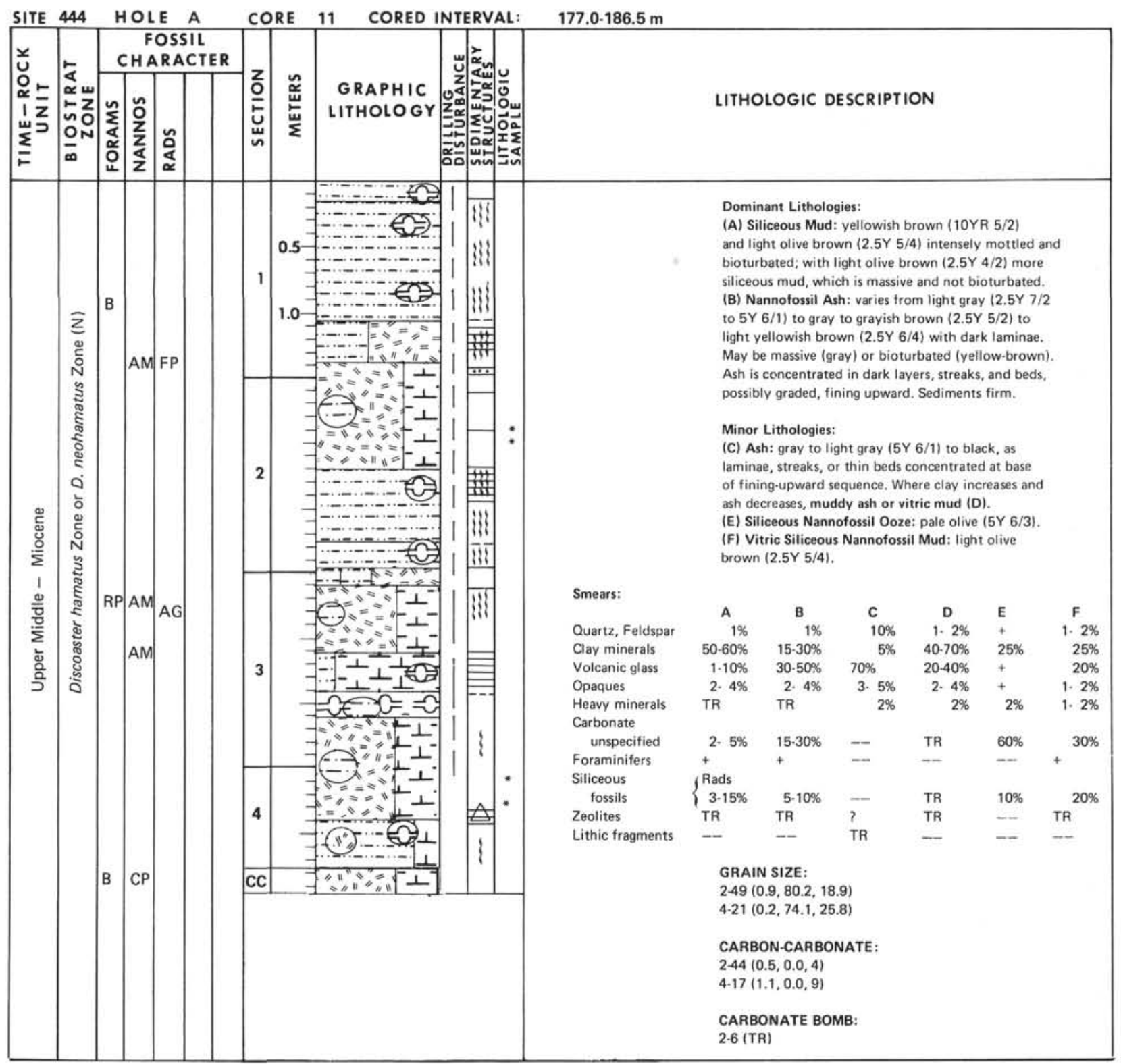

Figure 3. Typical core-description sheet for sediments. Symbols and notations are explained in the text and in other figures in this chapter.

\section{Smear Slides}

Sediments were named on the basis of visual estimates of texture and composition in smear slides made aboard ship. These estimates are of areal abundances on the slide and may differ somewhat from more-accurate laboratory analyses of grain size, carbonate content, and mineralogy. Experience has shown that distinctive minor components can be accurately estimated $( \pm 1$ or $2 \%$ ), but that an accuracy of \pm 10 per cent for major constituents is rarely attained. Carbonate content is especially difficult to estimate in smear slides, as is the amount of clay. The locations in the core of smear-slide samples are indicated in the "Lithologic Sample" column of the core-description sheets.

\section{Sediment Induration}

The determination of induration is highly subjective, but field geologists have made such determinations successfully for many years. The criteria of Moberly and Heath (1971) are used for calcareous deposits; subjective estimate or behavior in core cutting is used for others (Table 2).

\section{Biostratigraphy and Basis for Age Determination}

Microfossil zonation of sediments cored on Leg 58 (see appropriate tables in the site-report chapters, this volume) is based on the following references: 
INTRODUCTION AND EXPLANATORY NOTES

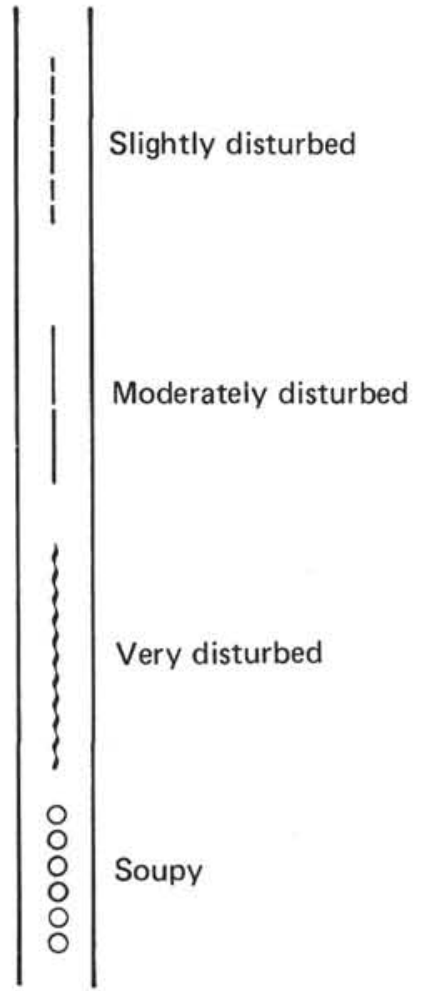

Figure 4. Drilling-disturbance symbols used on coredescription sheet.

Foraminifers: Berggren and van Couvering (1974); van Andel et al. (1975); Saito (1977); Haq et al. (1977). See also Echols (this volume).

Nannofossils: Bukry's $(1973,1975)$ zonation is used primarily; zone boundaries in the Pleistocene are modified on the basis of recent work done by Gartner (1977), Thierstein et al. (1977), and Haq et al. (1977). See also Okada (this volume).

Radiolarians: Zonation for radiolarians is based on Riedel and Sanfilippo (1978). See also Sloan (this volume).

The following letters are used on core-description sheets to indicate fossil abundance:

A $=$ abundant (flood, many species and specimens);

$\mathrm{C}=$ common (many species, easy to make age assignment);

$\mathrm{R}=$ rare (enough for age assignment);

$\mathrm{T}=$ trace (few species and specimens, not enough for age assignment);

$\mathrm{B}=$ barren.

Letters used to designate fossil preservation are:

$\mathrm{E}=$ excellent (no dissolution or abrasion);

$\mathrm{G}=$ good (very little dissolution or abrasion);

$\mathrm{M}=$ moderate (dissolution and/or abrasion and/or recrystallization very noticeable);

$\mathrm{P}=$ poor (substantial or very strong evidence of dissolution and/or abrasion, and/or recrystallization).

\section{Sediment Classification}

The sediment classification is basically that devised by the JOIDES Panel on Sedimentary Petrology and Physi-

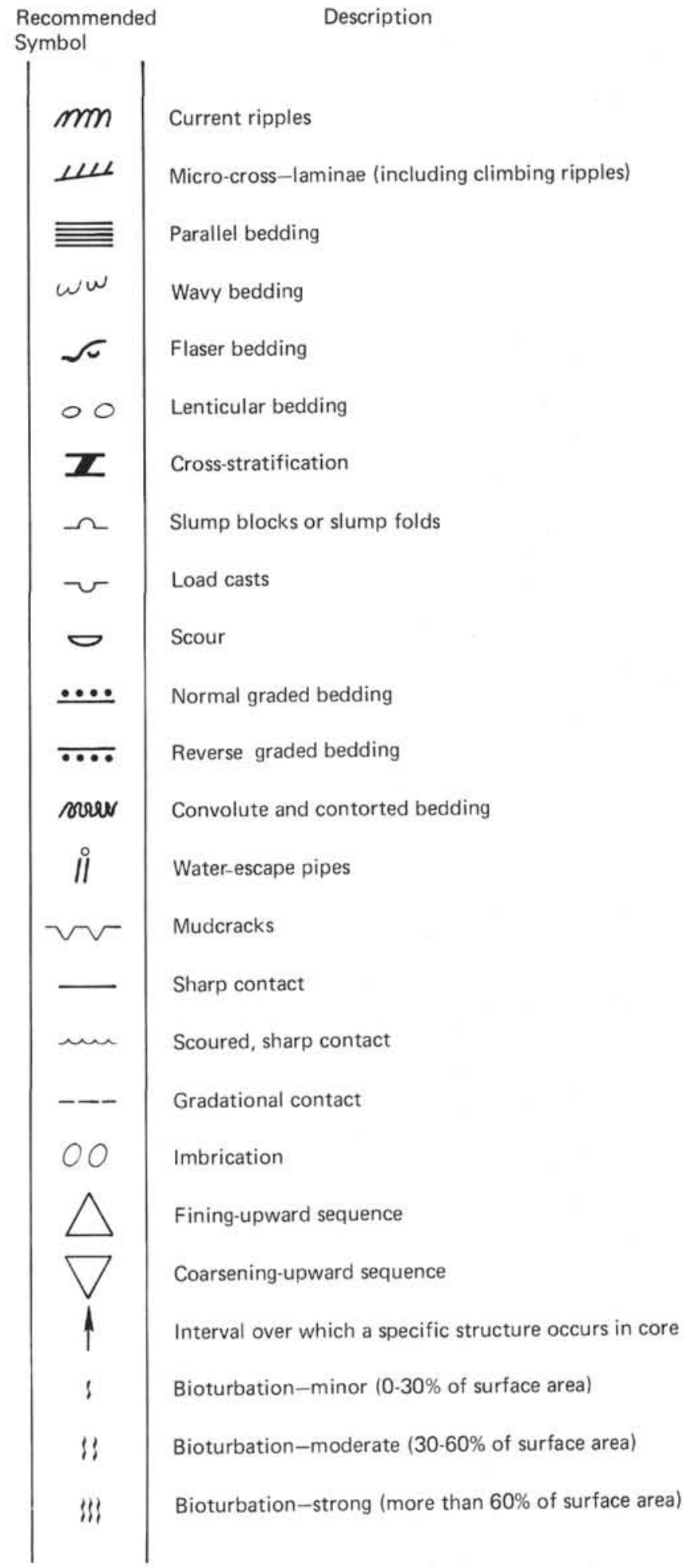

Figure 5. Sedimentary-structure symbols for core-description sheets. (Some not used in this volume.)

cal Properties and adopted with minor modifications by the JOIDES Planning Committee in March 1974. The general classification (which embraces several lithologies not encountered during Leg 58) is outlined below. Lithologic symbols used on the core-description sheets are shown in Figure 6. 


\section{SYMBOLS FOR DOMINANT SEDIMENT TYPES}

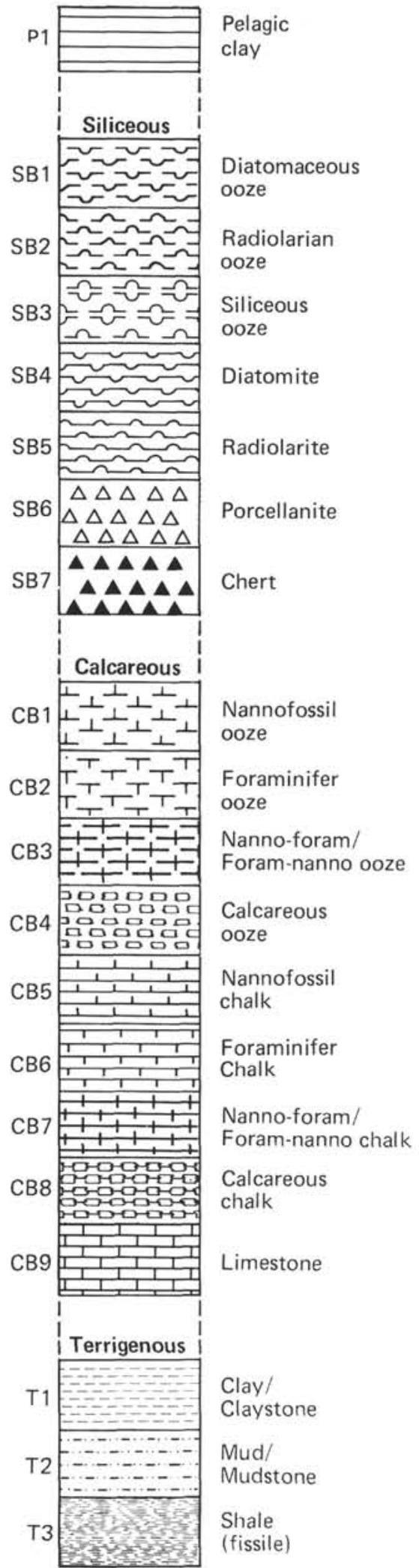

\section{OVERPRINT SYMBOLS}

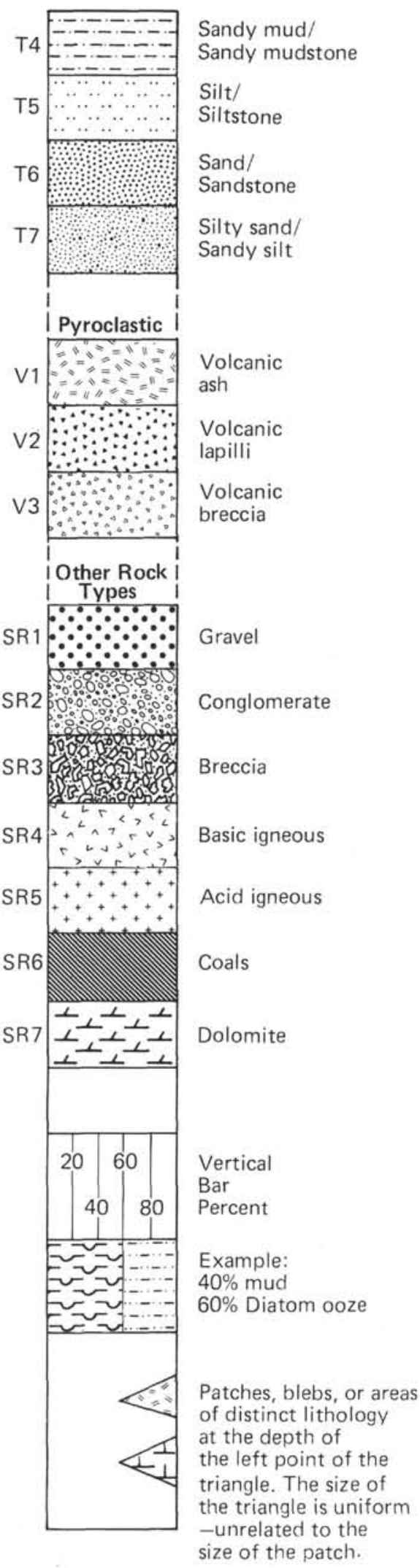

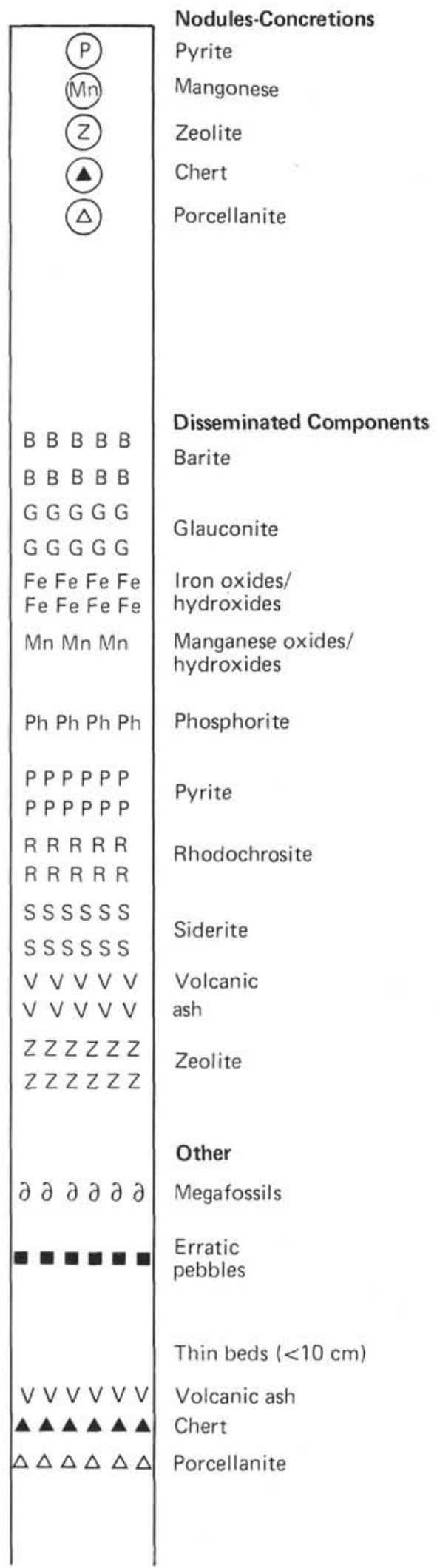

Figure 6. Lithologic symbols for core-description sheets and various figures (some not used in this volume). 


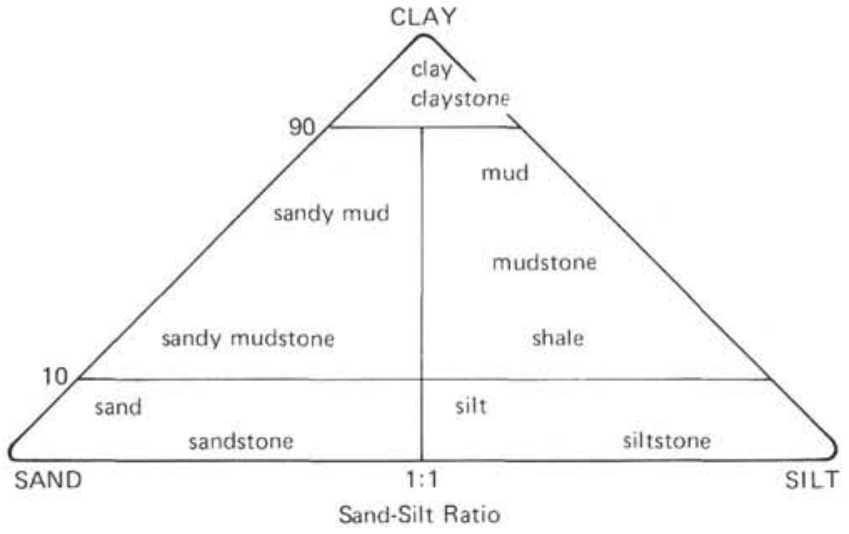

Figure 7. Textural classification of clastic sediments.

TABLE 2

Scheme of Sediment Induration

\begin{tabular}{l|l|l|l|l|l}
\hline \multirow{2}{*}{} & \multicolumn{3}{|c|}{ Calcareous Sediments } & \multicolumn{1}{c}{ Non-calcareous Sediments } \\
\cline { 2 - 6 } & \multicolumn{1}{|c|}{ Soft } & \multicolumn{1}{c|}{ Firm } & Hard & \multicolumn{1}{c}{ Soft } & \multicolumn{1}{c}{ Hard } \\
\hline $\begin{array}{l}\text { Criteria of } \\
\text { Induration }\end{array}$ & $\begin{array}{l}\text { Little strength, } \\
\text { readily deformed } \\
\text { under finger or } \\
\text { blade of spatula }\end{array}$ & $\begin{array}{l}\text { Partly cemented, } \\
\text { friable, readily } \\
\text { deformed under } \\
\text { fingernail or edge } \\
\text { of spatula }\end{array}$ & $\begin{array}{l}\text { Cemented, } \\
\text { not friable }\end{array}$ & $\begin{array}{l}\text { Soft enough } \\
\text { to be split } \\
\text { with wire } \\
\text { cutter }\end{array}$ & $\begin{array}{l}\text { Must be cut with } \\
\text { band or diamond } \\
\text { saw }\end{array}$ \\
\hline Name & Ooze & Chalk & Limestone & $\begin{array}{l}\text { Clay, sand, } \\
\text { etc. }\end{array}$ & $\begin{array}{l}\text { Claystone, Sand- } \\
\text { stone, etc. }\end{array}$ \\
\hline
\end{tabular}

1. General rules for class limits and order of components present in a sediment name.

A. Sediment assumes only the names of those components present in quantities greater than 15 per cent.

B. Where more than one component is present, the component in greatest abundance is listed farthest to the right, and other components are listed progressively to the left in order of decreasing abundance.

C. The class limits are based on percentage intervals given below for various sediment types.

2. Compositional class boundaries.

A. $\mathrm{CaCO}_{3}$ content (determined by carbonate bomb). Class boundaries of 30 and 60 per cent. Given the natural frequency distribution of $\mathrm{CaCO}_{3}$ contents in oceanic sediments, these boundaries can be ascertained with a precision of 5 per cent.

B. Biogenic-opal abundance.

Expressed as per cent siliceous skeletal remains in smear slides. Class boundaries at 10,30 , and 50 per cent. Smear-slide estimates of identifiable siliceous skeletal material generally imply a significantly higher total opal abundance. The boundaries have been set to take this into account.

C. Abundance of authigenic components.

Zeolites, $\mathrm{Fe}$ and $\mathrm{Mn}$ micronodules, fish bones, and other indicators of very slow sedimentation (estimated in smear slides); semiquantitative boundary: common 10 per cent. These components are very conspicuous, and a semiquantita- tive estimate is adequate. Even a minor influx of calcareous, siliceous, or terrigenous material will, because of the large difference in sedimentation rate, dilute them to insignificance.

D. Abundance of Terrigenous Detrital Material.

Estimated from smear slides: 30 per cent.

E. Qualifiers.

Numerous qualifiers are suggested; the options should be used freely. However, components of less than 5 per cent (in smear slide) should not be used as a qualifier except in special cases.

3. Description of Sediment Type (Figure 6)

A. Pelagic Clay.

Principally authigenic pelagic deposits that accumulate at very slow rates. The class is often termed brown clay, or red clay, but since these terms are confusing, they are not recommended.

i. Boundary with Terrigenous Sediments.

Where authigenic components ( $\mathrm{Fe}$ and $\mathrm{Mn}$ micronodules, zeolites), fish debris, etc., become common in smear slides. NOTE: Because of large discrepancy in accumulation rates, transitional deposits are exceptional.

ii. Boundary with Siliceous Biogenic Sediments. $<30$ per cent identifiable siliceous remains.

iii. Boundary with Calcareous Biogenic Sediments.

Generally the sequence is one passing from pelagic clay through siliceous ooze to calcareous ooze, with one important exception: at the base of many oceanic sections, black, brown, or red clays occur directly on basalt, overlain by or grading up into calcareous sediments. Most of the basal clayey sediments are rich in iron, manganese, and metallic trace elements. For proper identification, they require more-elaborate geochemical work than can be done on shipboard. These sediments are placed in the "Special Rock" category, but care should be taken to distinguish them from ordinary pelagic clays.

B. Pelagic Siliceous Biogenic Sediments.

These are distinguished from the previous category because they have more than 30 per cent identifiable siliceous microfossils. They are distinguished from the following category by a $\mathrm{CaCO}_{3}$ content of less than 30 per cent. There are two classes: pelagic biogenic siliceous sediments (containing less than $30 \%$ silt and clay), and transitional biogenic siliceous sediments (containing more than $30 \%$ silt and clay and more than $10 \%$ diatoms).

i. Pelagic Biogenic Siliceous Sediments.

a. Soft: Siliceous ooze (radiolarian ooze, diatomaceous ooze, depending on dominant component).

b. Hard: Radiolarite, porcellanite, diatomite, and chert.

c. Qualifiers: Radiolarians dominant radiolarian ooze or radiolarite. 
Diatoms dominant - diatom ooze or diatomite.

Where uncertain - siliceous (biogenic) ooze, chert, or porcellanite; when containing $>10$ per cent $\mathrm{CaCO}_{3}$, qualifiers are as follows:

Indeterminate Carbonate: Calcareous.

Nannofossils Only: Nannofossil.

Foraminifers Only: Foraminiferal.

Nannofossil-Foraminiferal.

Depending on dominant component:

Foraminiferal-Nannofossil.

ii. Transitional Biogenic Siliceous Sediments.

Diatoms $<50$ per cent - diatomaceous mud (soft) or diatomaceous mudstone (hard).

Diatoms $>50$ per cent - diatom ooze (soft) muddy diatomite (hard).

Radiolarian equivalents in this category are rare and can be specifically described.

C. Pelagic Biogenic Calcareous Sediments.

These are distinguished from the previous categories by $\mathrm{CaCO}_{3}$ content in excess of 30 per cent. There are two classes: pelagic biogenic calcareous sediments (containing less than $30 \%$ silt and clay), and transitional biogenic calcareous sediments (containing more than $30 \%$ silt and clay).

i. Pelagic Biogenic Calcareous Sediments.

a. Soft: calcareous ooze.

b. Firm: chalk.

c. Hard: indurated chalk.

The term limestone should be restricted to cemented rocks.

d. Compositional Qualifiers:

Principal components are: nannofossils and foraminifers. One or two qualifiers may be used, for example:

Foraminifers $(\%) \quad$ Name

$<10 \quad$ Nannofossil ooze, chalk,

$10-25$

limestone.

$25-50$

Foraminifer-nannofossil ooze.

$>50$

Nannofossil-foraminifer ooze.

Foraminifer ooze.

Calcareous sediments containing more than 10 to 20 per cent identifiable siliceous fossils carry the qualifier "radiolarian," "diatomaceous," or "siliceous," depending on the quality of the identification - for example, "radiolarian-foraminifer ooze."

ii. Transitional Biogenic Calcareous Sediments. a. $\mathrm{CaCO}_{3} 30$ to 60 per cent: Marly calcareous pelagic sediments.

Soft: Marly calcareous (or nannofossil, foraminifer, etc.) ooze.

Firm: Marly chalk.

Hard: Marly limestone.

b. $\mathrm{CaCO}_{3}>60$ per cent: Calcareous pelagic sediments.
Soft:

Calcareous (or nannofossil, foraminiferal, etc.)

Firm: ooze.

Hard: Limestone.

NOTE: Sediments containing 10 to 30 per cent $\mathrm{CaCo}_{3}$ fall in other classes where they are denoted with the adjective "calcareous." Less than 10 per cent $\mathrm{CaCo}_{3}$ is ignored.

D. Terrigenous Sediments.

i. Sediments falling in this portion of the classification scheme are subdivided into textural groups on the basis of the relative proportions of clay, silt, and sand. Rocks coarser than sand size are treated as "Special Rock Types." The size limits for these constituents are those defined by Wentworth (1922).

Five major textural groups are recognized. These groups are defined according to the abundance of clay $(>90 \%, 90-10 \%,<10 \%)$ and the ratio of sand to silt $(>1$ or $<1)$.

Sands and sandstones may be subdivided further into very fine-, fine-, medium-, coarse-, or very coarse-grained sands and sandstones according to their median grain size.

Qualifiers: In this group numerous qualifiers are possible, usually based on minor constitutents, for example: glauconitic, pyritic, feldspathic. In the sand and sandstone category, conventional divisions such as arkose, graywacke, etc., are, of course, acceptable, providing the scheme is properly identified. Clays, muds, silts, and sands containing 10 to 30 per cent $\mathrm{CaCO}_{3}$ are called calcareous.

ii. Clastic sediments of volcanic provenance are described in the same fashion as the terrigenous sediments, noting the dominant composition of the volcanic grains where possible.

E. Special Rock Types.

The definition and nomenclature of sediment and rock types not included in the system described above are left to the discretion of shipboard scientists, with the recommendation that they adhere as closely as is practical to conventional terminology. In this category fall such rocks as:

Intrusive and extrusive igneous rocks.

Evaporites, halite, anhydrite, gypsum (as a rock), etc.

Shallow-water limestone (biostromal, biohermal, coquina, oolite, etc.).

Dolomite.

Gravels, conglomerates, breccias.

F. Volcanogenic Sediments.

Pyroclastic rocks are described according to the textural and compositional scheme of Went- 
worth and Willaims (1932). The textural groups are:

$>32 \mathrm{~mm}$ : Volcanic breccia.

32-4 mm: Volcanic lapilli.

$<4 \mathrm{~mm}$ : Volcanic ash (tuff when indurated).

These pyroclastic rocks are described as vitric (glass), crystal, or lithic. Sediments rich in ash are described in the following manner:

$\%$ Ash Soft Sediment Indurated

0-10 Mud Mudstone

10-30 Vitric mud Vitric mudstone

30-60 Muddy ash Tuffite ash

$>60$ Ash Tuff

In general, sediments containing various constituents in the 10 to 30 per cent range may be identified in the name of sediment, such as "vitric diatomaceous mud" or "vitric muddy diatomaceous ooze." If more than one such qualifier is used, they are listed in order of increasing abundance in the sediment.

\section{Basement-Description Conventions}

\section{Core Forms}

Core-description forms for igneous and metamorphic rocks are not the same as those used for sediments. The latter are essentially those published in previous Initial Reports. Igneous rock representation on such sheets, however, is too compressed to provide adequate information for rock sampling. Consequently, visual-coredescription forms, modified from those used on board ship, are used here for more-complete graphic representation. Each of these forms covers one 1.5-meter section. All shipboard chemical- and physical-property data, as well as summary hand-specimen and thinsection descriptions, are presented for each section.

All basalts were split with rock saw into archive and working halves. The working half was described and sampled on board ship. In a typical basalt description form (Figure 8), the left box is a visual representation of the working half. Two closely spaced horizontal lines in this column indicate the location of styrofoam spacers taped between basalt pieces inside the liner. Each piece is numbered sequentially from the top of each section, beginning with the number 1 . Pieces are labeled on the rounded, not the sawed surface. Pieces which could be fit together before splitting are given the same number, but are lettered consecutively, as "1A, 1B, 1C," etc. Spacers are placed between pieces with different numbers, but not between those with different letters and the same number. In general, addition of spacers represents a drilling gap (no recovery). All pieces which are cylindrical and longer than the liner diameter have orientation arrows pointing up, both on the archive and working halves. Special procedures were adopted to ensure that orientation was preserved through every step of the sawing and labeling process. All orientable pieces are indicated by upward-pointing arrows to the right of the graphic representation on the description forms. Because the pieces were rotated during drilling it is not possible to sample for declination studies.

Samples were taken for various measurements on board ship. The type of measurement and approximate location are indicated in the column headed "Shipboard Studies," using the following notation:

$\mathrm{X}=\mathrm{X}$-ray fluorescence and CHN chemical analysis.

$\mathbf{M}=$ magnetism measurement.

$\mathrm{S}$ = sonic-velocity measurement.

$\mathrm{T}=$ thin section.

$\mathrm{D}=$ density measurement.

$\mathrm{P}=$ porosity measurement.

The state of alteration (see Figure 8 for symbols) is shown in the column labeled "Alteration."

On Leg 58, some pieces were stored permanently in salt water. These are labeled with a "W" in the "special Storage" column.

\section{Igneous- and Metamorphic-Rock Classification}

Basalt and breccia were recovered on Leg 58. Classification is based mainly on mineralogy and texture. Thin-section work in general added no new information to the hand-specimen classification.

Basalts are termed aphyric, sparsely phyric, moderately phyric, or phyric, depending on the proportion of phenocrysts visible with the binocular microscope $(\sim \times 12)$. Basalts are called aphyric if phenocrysts are absent. For practical purposes, this means that if one piece of basalt was found with a phenocryst or two in a section where all other pieces lack phenocrysts, and no other criteria, such as grain size or texture, distinguish this basalt from the others, then it too is described as aphyric. A note of the rare phenocrysts is included in the general description, however. This approach enables us to restrict the number of lithologic units to those with clearly distinctive and persistent visible differences.

Sparsely phyric basalts are those with 1 to 2 per cent phenocrysts in almost every piece of a given core or section. Clearly contiguous pieces without phenocrysts are included in this category, the lack of phenocrysts again noted in the general description.

Moderately phyric basalts contian 2 to 10 per cent phenocrysts. Aphyric basalts within a group of moderately phyric basalts are separately termed aphyric basalts.

Phyric basalts contain more than 10 per cent phenocrysts. No separate designation is made for basalts with more than 20 per cent phenocrysts; the proportion indicated in the core forms should be sufficient to guide the reader.

The basalts are further classified by phenocryst type, and a modifying term precedes the terms phyric, sparsely phyric, etc. A plagioclase-olivine, moderately phyric basalt contain 2 to 10 per cent phenocrysts, most of them plagioclase, but with some olivine. 


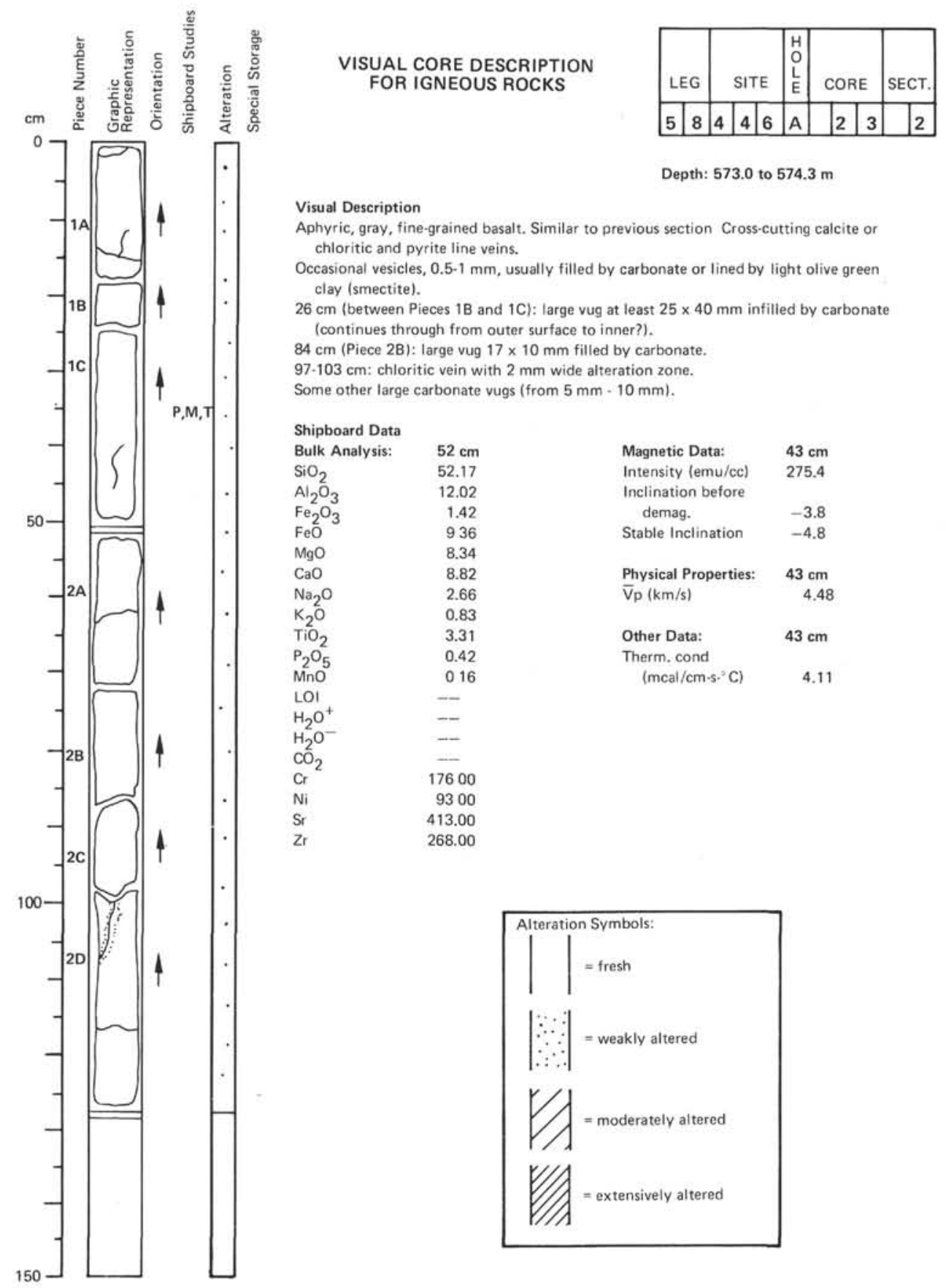

Figure 8. Typical core-description sheet for igneous rocks.

\section{Data Presentations}

\section{Carbonate Bomb}

Per cent $\mathrm{CaCo}_{3}$ was also determined on board ship by the "Karbonate Bomb" technique (Müller and Gastner, 1971). In this simple procedure, a sample is powdered and treated with $\mathrm{HCl}$ in a closed cylinder. Any resulting $\mathrm{Co}_{2}$ pressure is proportional to the $\mathrm{CaCO}_{3}$ content of the sample. Application of the calibration factor to the manometer reading $(\times 100)$ yields per cent $\mathrm{CaCo}_{3}$. Per cent error can be as low as 1 per cent for sediments high in $\mathrm{CaCo}_{3}$, and in general an accuracy of about 2 to 5 per cent can be obtained.

These data are presented on the core-description sheets. The sample interval is designated by two numbers: the section number, followed by the top of the sample interval. For example, a sample from Section 2, 11 to $12 \mathrm{~cm}$, with 90 per cent calcium carbonate will be represented on the core-description sheet as "2-11 $(90 \%)$."

The carbon-carbonate data are also presented on the core-description sheet. The sample interval is designated 
by two numbers: the section number, followed by the top of the sample interval. For example, a sample from Section 2, at $45 \mathrm{~cm}$, with 0.8 per cent total carbon, 0.6 per cent organic carbon, and 2 per cent calcium carbonate will be represented on the core-description sheet as follows:

TOTAL C - ORGANIC C - CARBONATE (\%)

$2-45 \mathrm{~cm}(0.8,0.6,2)$

\section{Grain-Size Analysis}

Distribution of sand-size, silt-size, and clay-size particles was determined from $10-\mathrm{cm}^{3}$ sediment samples at the DSDP sediment laboratory by standard sieve and pipette methods (Initial Reports, 4, 745, with modified settling times as in Boyce, 1972). The sand, silt, and clay boundaries are based on the Wentworth (1922) scale. (class boundaries 2000, 62.5, and $3.91 \mu \mathrm{m}$ ).

Grain-size data are presented on the core-description sheets. The sample interval is designated by two numbers: the section number and the top of the sample interval within that section.

\section{X-Ray Data (sediments)}

Mineralogical data were obtained on samples dried at $70^{\circ} \mathrm{C}$, powdered, and $\mathrm{X}$-rayed under the following conditions: $\mathrm{CuK}_{\alpha}$ radiation, nickel filter, $35 \mathrm{KV} / 24 \mathrm{~mA}, 1^{\circ}$ detection slit. Goniometer speed was $0.5^{\circ} \mathrm{min}$., paper speed $10 \mathrm{~mm} / \mathrm{min}$. All samples were X-rayed from 3 to $40^{\circ}=2 \theta$.

For identification of the clay minerals, smear slides were made. To get optimal texture, the $<2-\mu \mathrm{m}$ fraction was first disintegrated with a KLN 582 ultrasonic generator and then centrifuged to clearness. The residue was mixed to a homogeneous paste and placed on the glass slide. It was X-rayed in an untreated state, glycolated, and, when necessary, heated (see Müller, this volume).

Samples from Hole 443 were submitted to X-raydiffraction analysis on $2-\mu \mathrm{m}$ decalcified particles. Some of the $<8-\mu \mathrm{m}$ fractions were observed by transmission electron microscopy.

The X-ray diffraction method is as follows: the samples are dissociated in water, then decarbonated in $5 N$ hydrochloric acid. The excess acid is removed by successive centrifugations. Microhomogenization produces deflocculation. The $<2-\mu \mathrm{m}$ fraction is collected by decantation, using Stokes law, and then oriented aggregates are made on glass slides. A GGR $\Theta 60$ diffractometer (copper radiation focused by a quartz curved-crystal monochromator) was used to run the $\mathrm{X}$-ray-diffraction scans at $1 \% \mathrm{~min}$. A receiving slit of $1.25 \mathrm{~mm}$ allowed a better determination of mixed-layer minerals. Four passages are carried out as follows: (1) from $1^{\circ}$ to $15^{\circ} \theta$ on the natural sample; (2) from $1^{\circ}$ to $7^{\circ} \Theta$ on a glycolated sample; (3) from $1^{\circ}$ to $7^{\circ} \theta$ on a sample heated for two hours at $490^{\circ} \mathrm{C}$; (4) from $12^{\circ}$ to $14^{\circ} \Theta$ on a hydrazine-hydrated sample. Semi-quantitative evaluations are based on the peak heights and areas. The height of 001 illite and chlorite peaks (diagram of glycolated samples) are taken as references. Compared to these values, smectite, attapulgite, sepiolite, vermiculite, and irregular mixed-layer species are corrected by addition of peak height, whereas well-crystallized kaolinite is corrected by subtraction. The proportions of chlorite and kaolinite are obtained from peak-height ratios 3.54 and $3.58 \AA$ respectively. When this ratio is 1 , the amount of chlorite is assumed to be twice that of kaolinite. Final data on Hole 443 core-description sheets are given in percentages, the relative error being about 5 per cent.

\section{X-Ray Data (basalts)}

\section{Birmingham XRF System}

This system is based on a Philips PW1450 spectrometer equipped with $2-3 \mathrm{~kW}$ chromium, tungsten, and molybdenum, high-energy-X-ray tubes. All analyses were performed at the University of Birmingham, England. The machine analyzes 60 samples automatically each 24 -hr period ( 2 cycles), the elements being divided into the following tube programs for maximum sensitivity:

C-tube: $\mathrm{SiO}_{2}, \mathrm{TiO}_{2}, \mathrm{Al}_{2} \mathrm{O}_{3}, \mathrm{Fe}_{2} \mathrm{O}_{3}, \mathrm{MnO}, \mathrm{MgO}$, $\mathrm{CaO}, \mathrm{Na}_{2} \mathrm{O}, \mathrm{K}_{2} \mathrm{O}, \mathrm{P}_{2} \mathrm{O}_{5}, \mathrm{~S}, \mathrm{Cl}$.

Mo-tube: $\mathrm{Rb}, \mathrm{Sr}, \mathrm{Y}, \mathrm{Th}, \mathrm{Pb}, \mathrm{Cu}, \mathrm{Zn}, \mathrm{Ga}, \mathrm{Ba}$.

W-tube: $\mathrm{Cr} / \mathrm{V}, \mathrm{Ni}, \mathrm{Ce}, \mathrm{La}, \mathrm{Zr}, \mathrm{Nb}$.

High precision for trace elements is also gained by (1) using large-area, pressed-powder pellets $(4.6 \mathrm{~cm})$; (2) ratioing each group of 3 samples to a resin-bonded standard; (3) running a standard of known composition every twelfth sample; (4) running international standards at regular intervals. Corrections for interfering elements are made in the computer program, and matrix effects are corrected for by using Mo Compton and $\mathrm{WL} \beta$ tube lines to select the appropriate calibration factors.

Major-element analyses are carried out using lithium tetraborate/metaborate fusion discs, or by a combination of fusion discs and powder pellets over a restricted compositional range. Fusion calibrations are based on international standards and synthetic binaries.

\section{Sample Preparation}

For high-precision trace analysis, a large-diameter powder disc is needed, weighing 15 grams. The powder is bonded with a few drops of polyvinyl alcohol solution (MOWIOL), but is not destroyed and can be reground if necessary for other analytical purposes. Additionally, a further 1 gram is needed for making fusion beads (major elements).

\section{Procedures Used in the \\ Measurement of Physical-Chemical Properties}

\section{Physical Properties}

A thorough discussion of physical properties is presented by Boyce (1973) with regard to equipment, methods, errors, correction factors, presentation, and coring disturbance relative to the validity of the data. Only a brief review is given here. 
The physical properties are presented in graphic form and discussed in each site chapter. Explanaton of some measuring techniques and data processing follows.

1. Sediment water content $(W)$ is defined as the weight of water in the sediment divided by the weight of the saturated wet sediment.

2. Sediment porosity $(\Phi)$ is defined as the volume of pore space divided by the volume of the water-saturated sample and is expressed as a percentage. Porosities calculated from $W$ are not plotted. The continuous plots of porosity (site summaries only) are otained from the GRAPE densities, assuming a mean grain density of $2.67 \mathrm{~g} / \mathrm{cm}^{3}$ and a water density of $1.024 \mathrm{~g} / \mathrm{cm}^{3}$.

3 . Wet-bulk density $(\rho)$ is defined as the weight in $\mathrm{g} / \mathrm{cm}^{3}$ of the water-saturated sediment, i.e.,

$$
\rho=\frac{\text { weight of wet sediment }}{\text { volume of wet sediment }\left(\mathrm{cm}^{3}\right)}
$$

Densities of the sea-water-saturated cores were measured in three ways: (a) by weighing each 1.5 -meter core section, giving a mean density for the whole core; (b) by proceeding from the water content, $W$ (syringe samples); and (c) by continuously measuring along the length of the core section with the GRAPE, using as standards water $\left(1.024 \mathrm{~g} / \mathrm{cm}^{3}\right)$ and aluminum $(2.6$ $\left.\mathrm{g} / \mathrm{cm}^{3}\right)$. The GRAPE technique is described by Evans and Cotterell (1970) and Whitmarsh (1972). Because of the possible presence of drilling slurries and disturbances, low values are suspect, and emphasis should be placed on the maximum densities (minimum porosities).

4. Compressional wave velocity is obtained by timing a $400-\mathrm{kHz}$ sonic pulse across two transducers and measuring the distance across the sample with a dial gauge (Hamilton Frame method). Measurements were made at laboratory temperature and pressure, a time delay of about 4 hours being allowed for the cores to reach equilibrium. The accuracy is about 2 per cent. The values $(\mathrm{km} / \mathrm{s})$ are plotted on forms in the site chapters.

5. Thermal conductivity is defined as the quantity of heat transmitted, due to unit temperature gradient, in unit time in steady conditions in a direction normal to a surface of unit area.

Thermal conductivities were measured with Showa Denko K. K. QTM [Quick Thermal (Conductivity) Meter]. See physical-property reports in the site chapters (this volume).

6. Shear strength was measured with the $\mathrm{Cl}-600$ Torvane on board ship; it is a scientifically designed soiltesting instrument for the rapid determination of shear strength of cohesive soils, either in the field or in the laboratory. The instrument permits rapid determination of a large number of strength values with various orientations of failure planes.

The shear strength of a cohesive soil is dependent upon many factors, including rate of loading, progressive failure, orientation of the failure plane, and pore-water migration during testing. The instrument does not eliminate the effects of any of these variables. However, it does give repeatable values in a homogeneous clay, and extensive laboratory testing indicates excellent agreement between the unconfined-compression test and the Torvane. The smallest division on the dial is in units of 0.05 tons per square foot (TSF), permitting visual interpolation to the nearest $0.01 \mathrm{TSF}$.

Measurements made on the working halves not only provided shear-strength data, but also revealed the degree of coring disturbance. For this reason alone, the instrument is very useful, especially when no lithologic or color differences indicate coring deformations. For shear-strength values throughout the sediment of one hole, only the highest values (normally obtained only in the lowest section) should be used. Discussions of vane shear studies will be found in the site report chapters.

\section{Geochemical Measurements}

Aboard ship, analyses for $p \mathrm{H}$, alkalinity, and salinity are conducted routinely.

1. $p \mathrm{H}$ is determined by two methods. One is a flowthrough-electrode method; the other is a punch-inelectrode method. $p \mathrm{H}$ is determined on all samples by the flow-through method, which was glass-capillary electrode through which a small portion of unfiltered pore water is passed. In the softer sediments a "punched-in" $p \mathrm{H}$ is also determined by inserting $p \mathrm{H}$ electrodes directly into the sediment at ambient temperature prior to squeezing. The $p \mathrm{H}$ electrodes for both methods are plugged into an Orion digital millivolt meter.

2. Alkalinity is measured by colorimetric titration of a $1-\mathrm{ml}$ aliquot of interstitial water with $0.1 \mathrm{~N} \mathrm{HCl}$, using a methyl red/blue indicator. This formula is used:

$$
\text { Alkalinity }(\mathrm{meq} / \mathrm{kg})=(\mathrm{ml} \mathrm{HCl} \text { titrated }) \times(97.752)
$$

3. Salinity is calculated from the fluid refractive index, as measured by a Goldberg optical refractometer, using this expression:

$$
\text { Salinity }(\%=(0.55) \times \Delta N
$$

where $\Delta N=$ refractive index difference $\times 10^{4}$. Local surface sea water is regularly examined by each of these methods for reference. 